\title{
Why Did Projectile-Point Size Increase in the Andean Altiplano Archaic? An Experimental Atlatl Analysis
}

\author{
Caleb K. Chen, Luis Flores-Blanco, and Randall Haas
}

\begin{abstract}
Archaic projectile points from the Andean Altiplano exhibit a curious trend of increasing size over time, in contrast to a well-documented size reduction throughout North America. Although a number of hypotheses exist to account for decreasing projectile-point size, there are currently no explicit explanations for increasing size. We consider several hypotheses and interrogate two techno-economic hypotheses. We posit that increasing point size compensated for lost dart momentum or accuracy that resulted from the shortening of atlatls or atlatl darts as wood became increasingly scarce on the tree-sparse Altiplano. We evaluate these hypotheses using a replicated Andean atlatl system in ballistic trials. Contrary to expectation, results show that point enlargement significantly reduces penetration depth, allowing us to confidently reject the momentum hypothesis. Point enlargement, in contrast, tentatively correlates positively with accuracy. Our experiment further shows that camelid bone is an effective and economical alternative to wood for atlatl production. Despite suboptimal lengths, camelid radioulna atlatls have a convenient morphology that requires low production time, which helps explain empirically observed camelid bone atlatls from the Andean highlands. More generally, our observations lead us to consider that central tendencies in archaeologically observed projectile-point size may reflect a trade-off between penetration and accuracy.
\end{abstract}

Keywords: projectile points, allometry, atlatl, Andean Archaic, experimental archaeology

Las puntas de proyectil del periodo Arcaico del altiplano andino exhiben una tendencia de aumento de tamaño con el tiempo a diferencia de su reducción reportada en América del Norte. Existen varias hipótesis para explicar la disminución del tamaño, pero no para su aumento. Postulamos y exploramos dos hipótesis tecnoeconómicas, que el aumento del tamaño de las puntas compensó la pérdida de impulso o precisión del dardo que resultó del acortamiento de las átlatls o sus dardos a medida que la madera se volvía cada vez más escasa en el altiplano deforestado. Evaluamos estas hipótesis utilizando un sistema de estólica o átlatl andino replicado en ensayos balísticos. Contrariamente a lo esperado, los resultados muestran que el agrandamiento de la punta reduce significativamente la profundidad de penetración, lo que permite rechazar la hipótesis del impulso. La amplificación de las puntas, por el contrario, se correlaciona positivamente con la precisión. Nuestro experimento muestra además que el hueso de camélido fue una alternativa eficaz y económica a la madera para la producción de atlatls. A pesar de sus longitudes subóptimas, el hueso radiocubital de camélidos tiene una morfología que requiere un bajo tiempo de producción de las átlatls, lo que explicaría el uso de este material en las tierras altas andinas. De manera más general, proponemos que las tendencias centrales en el aumento del tamaño de las puntas de proyectil reflejarían una compensación entre su capacidad de penetración y precisión.

Palabras claves: puntas de proyectil, alometría, átlatl, Arcaico andino, arqueología experimental

$\mathrm{P}$ rojectile-point sizes tended to decrease over time in North America. This phenomenon has been variously attributed to the transition from atlatl to bow-and-arrow technology (Bettinger and Eerkens 1999; Whittaker et al. 2017), decreasing prey size (Tomka 2013), the invention of fletching (Hughes 1998), and stochastic cultural transmission processes in which flintknappers tend to create smaller points than those of their mentors

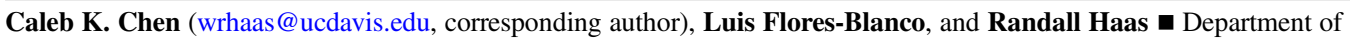
Anthropology, University of California, Davis, CA, USA

Latin American Antiquity 33(3), 2022, pp. 616-631

Copyright (C) The Author(s), 2021. Published by Cambridge University Press on behalf of the Society for American Archaeology. This is an Open Access article, distributed under the terms of the Creative Commons Attribution licence (http://creativecommons.org/licenses/by/4.0/), which permits unrestricted re-use, distribution, and reproduction in any medium, provided the original work is properly cited.

doi:10.1017/laq.2021.70 
because of copying errors (Hamilton and Buchanan 2009). On the Andean Altiplano, projectile-point size decreased dramatically after the apparent introduction of the bow and arrow around 3,000 years ago (de Souza 2004, 2011; Klink and Aldenderfer 2005). Although the trend of decreasing point size is common across many regions and time spans in the Americas (for a broader discussion of lithic miniaturization, see also Pargeter and Shea 2019), we observe what appears to be an unusual period of projectile-point enlargement on the Andean Altiplano over about 6,000 years between the Early and Late Archaic periods, $11-5$ cal ka (Klink and Aldenderfer 2005).

Early Archaic points of the Altiplano are notably small, whereas Middle and Late Archaic points are perceptibly larger (Figure 1). This qualitative pattern bears out quantitatively among several assemblages. Restifo's (2013) data from the high puna of northwest Argentina show that average projectile-point mass increased from approximately $3 \mathrm{~g}$ in the Early Holocene to approximately $20 \mathrm{~g}$ in the Middle Holocene. Complete surface-collected projectile points from the Ilave drainage west of Lake Titicaca similarly exhibit a statistically significant increase from approximately $3 \mathrm{~g}$ in the Early Archaic period to $6 \mathrm{~g}$ in the Middle and Late Archaic periods (Haas and Viviano Llave 2015; Figure 2). Data from the Ramis region north of Lake Titicaca show that average stem widths - measured near the stem/blade juncture - of surface-collected projectile points significantly increased from $13 \mathrm{~mm}$ in the Early Archaic period (11-9 cal ka) to $19 \mathrm{~mm}$ in the Late Archaic period (7-5 cal ka; see Figure 2).

The pattern of projectile-point enlargement in the Titicaca Basin is also evident in projectile points reported from the few directly dated contexts in the Titicaca Basin. The average mass of six complete Early Archaic projectile points from a $9.0 \mathrm{ka}$ burial at Wilamaya Patjxa is $3.1 \mathrm{~g}$ (Haas et al. 2020). Those points contrast with a large lanceolate Middle Archaic point weighing $10.7 \mathrm{~g}$ associated with a $7.4 \mathrm{ka}$ burial at Soro Mik'aya Patjxa (Haas and Viviano Llave 2015; Haas et al. 2017).

Given that the projectile-point forms found in the Titicaca Basin are found throughout the
Altiplano and that the pattern is observed in both the northern and southern Altiplano, it is likely that the trend can be interpolated throughout the Altiplano more generally. Although the pattern has not yet been systematically analyzed and reported, the qualitative and quantitative data summarized here strongly suggest a pattern of projectile-point enlargement throughout the Altiplano Archaic.

The observation of increasing projectile-point size in the Altiplano Archaic against a backdrop of decreasing point size across a larger time scale and elsewhere in the Americas raises the question of why projectile-point size should increase over time in those relatively rare cases. As a first approximation, we can readily imagine several models to explain the enlargement of projectile points across the Altiplano Archaic. An exogenous historical explanation might imagine that migrating populations entered the region bringing their cultural conventions for the production of larger projectile points that replaced smaller local forms, perhaps by chance or perhaps as part of intergroup competition that favored larger armaments.

An endogenous version of a competition model might suppose that competition and territoriality increased among local individuals or groups throughout the Archaic as populations grew. Individuals might have enlarged projectile points as threat displays. The use of threat displays has been observed in ethnographic contexts and among other species in competitive environments (Crivelli et al. 2016; Ladich 1990; Scott and Fredericson 1951). In favor of these two competition hypotheses, evidence of increasing population has been consistently found on the Andean Altiplano (Craig 2011; Gayo et al. 2015; Klink 2005; Marsh 2014; Muscio and Lopez 2016; Vining et al. 2018). Moreover, violence has been observed as perimortem traumas in the Middle-Late Archaic osteological remains at the site of Soro Mik'aya Patjxa, 8.0-6.5 cal ka, suggestive of a competitive environment at that time (Haas and Viviano Llave 2015).

An alternative endogenous model, which considers techno-functional drivers, might suppose that the emergence of communal hunting strategies underwrote an increase in projectilepoint size. Aschero, Martínez, and Restifo have 


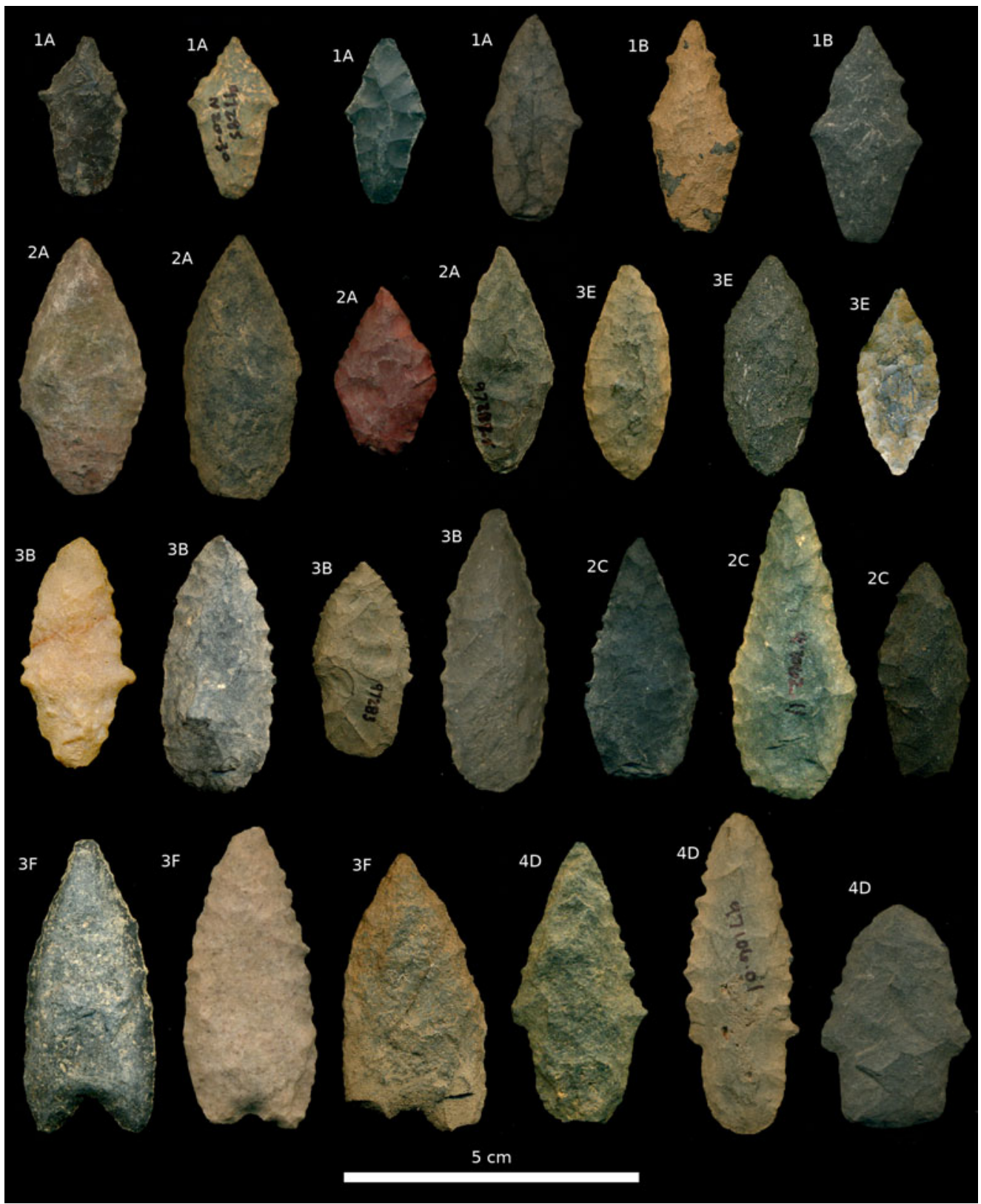

Figure 1. Examples of projectile-point forms of the Titicaca Basin. Top row, Early Archaic period (11-9 cal ka). Second row, Early/Middle Archaic period (10-8 cal ka). Third row, Middle Archaic period (9-7 cal ka). Bottom row, Late Archaic period (7-5 cal ka). Labels indicate types as defined by Klink and Aldenderfer (2005). Artifacts are from collections made by Klink (2005), Aldenderfer (Craig 2011), and Haas and colleagues (2015). (Color online)

suggested that communal hunting strategies may have appeared in the Archaic, and those strategies, which brought humans into close range with animals, may have favored the use of handheld spears that, in turn, would have favored the use of large stone points (Martínez and Aschero 2003; Martínez and Funes 2011; Restifo 2013; Restifo et al. 2019). In a review of ethnographic weapons systems, Ellis (1997) observed that stone-tipped spears indeed occur in special 

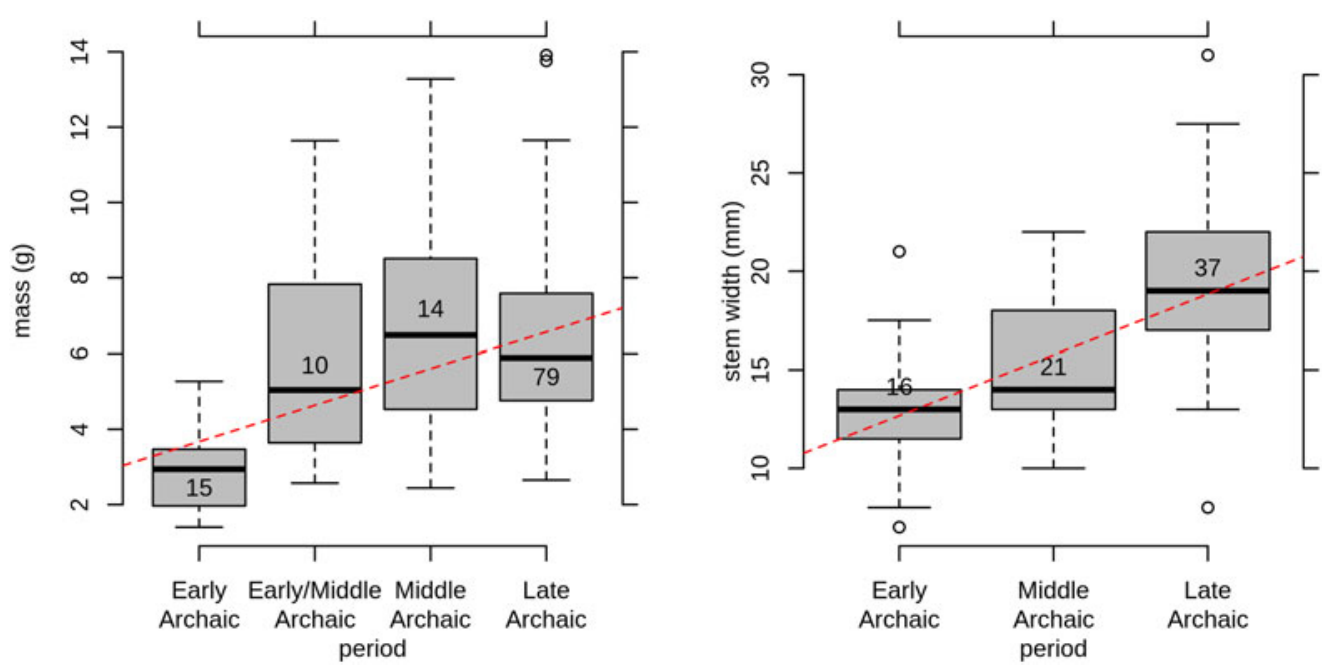

Figure 2. Projectile-point size increase in the Titicaca Basin. Left: projectile-point mass among complete points from the Ilave drainage shows a statistically significant increase as a function of time period $(3.1 \pm 0.6 \mathrm{~mm} / \mathrm{period}, t=5.3$, $p<0.01)$. Right: projectile-point stem width, measured at the stem/blade intersection, shows a statistically significant increase as a function of time period $(1.0 \pm 0.2 \mathrm{~g} /$ period, $t=4.8, p<0.01)$. Numbers overlaying the boxes indicate sample sizes for each period. Slope estimates and standard errors are solved using generalized linear models, and associated $t$ ratios and $p$-values assume Gaussian family dispersion (R Core Team 2020).

hunting circumstances. Although this is a plausible model for the Andean case, the extent to which stoned-tipped spears were used in the Andes remains unclear. To our knowledge there is currently no clear material evidence of stone-tipped spears in the Andes. In contrast, atlatls and associated artifacts are documented in the archaeological record (de Souza 2011; Fernández 1986; Núñez et al. 2006), and rock art scenes, including communal hunting scenes, commonly depict atlatl use (de Souza 2011; Hostnig 2018).

This article examines two alternative technofunctional hypotheses, which envision that increasing projectile-point size reflects technological adaptation to changing economic landscapes. One hypothesis considers that increasing projectile-point mass reflects an effort to increase dart penetration. The other hypothesis considers that the increasing mass reflects an effort to increase dart accuracy. At more than $3,800 \mathrm{~m}$ asl, few trees grow on the high plains or Altiplano. Only a single small tree taxon, queñual (Polylepis sp.), is endemic to the region (Winterhalder and Thomas 1978). The lack of wood on the Altiplano would have challenged the production of atlatlslikely the major hunting technology throughout the Archaic (de Souza 2011; Hostnig 2018; Núñez et al. 2006; see also Ellis 1997; Hughes 1998). Perhaps most problematic, atlatl systems require long, straight, small-diameter dart shafts of uniform thickness on the order of $2 \mathrm{~m}$ in length. The atlatl itself-typically comprising a straight or slightly arced stick-is on the order of $45 \mathrm{~cm}$ in length (Baugh 1998). High-quality atlatlproduction materials would have been limited in the Altiplano's treeless landscape and increasingly so as those resources were exhausted by continued harvesting and human population growth. Further exacerbating the wood supply problem, the Early-Middle Archaic transition was characterized by aridification and a decline in queñual forests (Craig et al. 2010; Rigsby et al. 2003). Lake Titicaca levels dropped approximately $100 \mathrm{~m}$ beginning around $8.5 \mathrm{cal}$ ka and did not recover until the Terminal Archaic period around $4.0 \mathrm{cal} \mathrm{ka}$ (Cross et al. 2001). Archaic hunter-gatherers would have needed to find ways to simultaneously make use of increasingly suboptimal wood materials while maintaining the effectiveness of their hunting implements.

One solution to increasing wood scarcity might have been the use of large mammal bone for the atlatl (Figure 3A). The use of camelid 


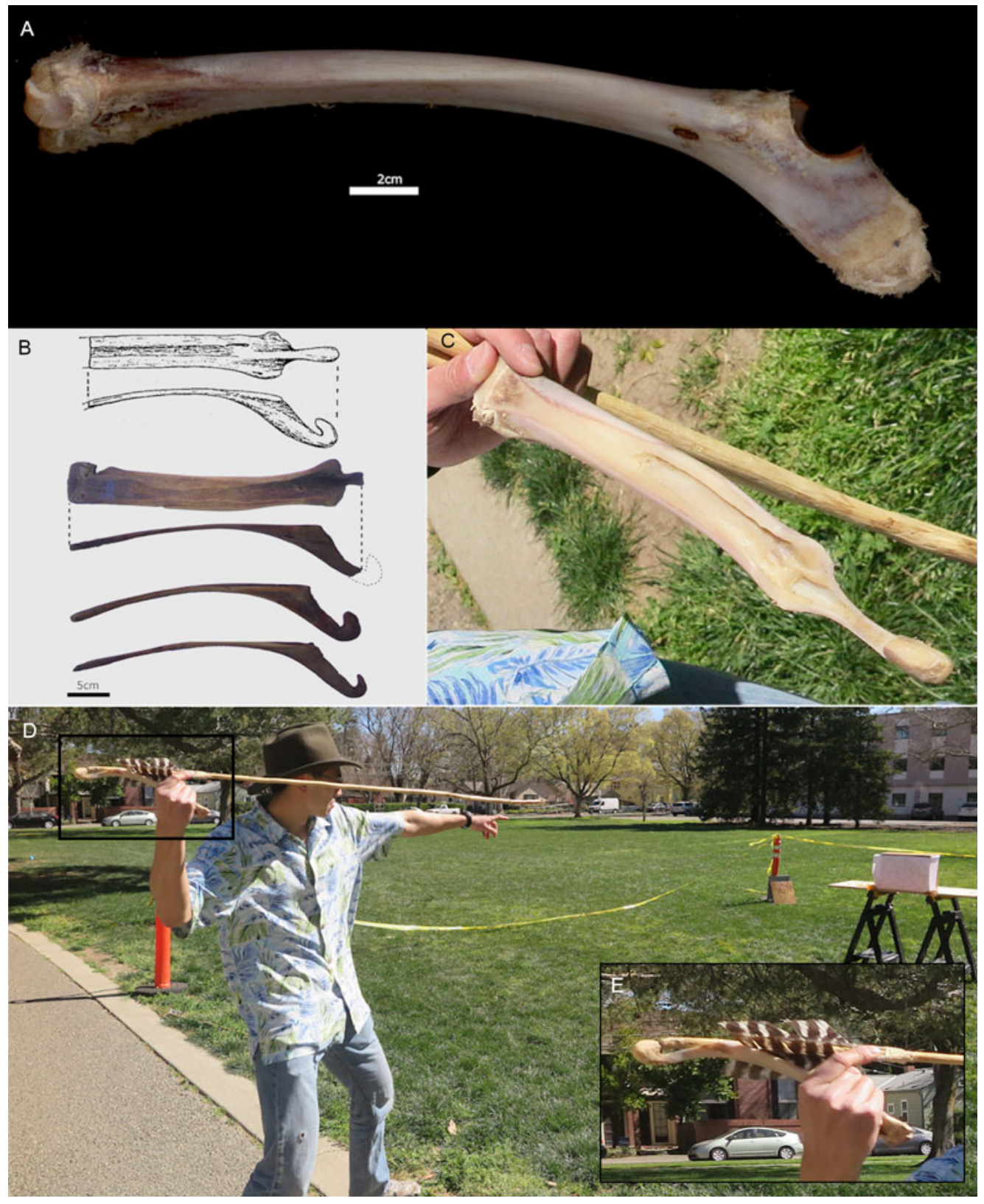

Figure 3. Bone atlatls and experimental design. (A) Alpaca radioulna used in this study before shaping; (B) archaeological camelid-radioulna atlatls from the Atacama Desert highlands (adapted from de Souza [2011] and reproduced with permission of the author); (C) experimental alpaca radioulna atlatl; (D) ballistic trial with atlatl, dart, target, and ballistic gel; (E) atlatl-dart articulation (photographs by Randall Haas). (Color online)

radioulna for this purpose is documented in specimens from the Chilean Atacama Desert highlands (de Souza 2011; Nuñez et al. 2006; Figure 3B). Camelid and deer bone would have been relatively accessible to Archaic period big- game hunters, solving part of the material-supply problem. However, this material alternative would have come at a cost. At approximately $25-35 \mathrm{~cm}$ long, camelid radioulna are short compared to optimal atlatl lengths. Because velocity 
increases with distance from a rotation point ( $v=r^{*} \omega$, where $v$ is velocity, $r$ is radius, and $\omega$ is angular velocity), the use of bone would tend to decrease a thrown dart's velocity. Baugh (1998) shows empirically that increasing atlatl length increases dart velocity until the atlatl exceeds its optimal length of $45 \mathrm{~cm}$, beyond which dart velocity decreases.

In addition, decreasing dart length would decrease dart mass, which could be expected to reduce the dart's penetration power, given that penetration is a function of force and momentum, each of which vary as a function of mass ( $f=m a$, where $f$ is force, $m$ is mass, and $a$ is acceleration; $p=m v$, where $p$ is momentum and $v$ is velocity). A simple and tractable solution to compensate for these performance losses could have been to increase the mass of foreshaft assembly. This could be accomplished by using dense woods for the foreshaft or increasing foreshaft size by, for example, carving them in such a way that left large bulges, as observed in an archaeological specimen from the Atacama (de Souza 2011; Núñez et al. 2006). Another practical solution, particularly when wood is scarce, would be to increase projectile-point mass. Such increases in foreshaft or projectile-point mass would have the effect of increasing dart momentum and thus, theoretically, affect force, penetration, and killing power (Hughes 1998; Whittaker et al. 2017). Importantly, increasing dart thickness would not be a viable option because proper atlatl functioning requires flexible darts to ensure proper oscillation during release (Hughes 1998).

A related effect of diminishing dart length and corresponding mass loss would have been reduced stability of a dart in flight, which would have the effect of diminishing accuracy. Reduced mass renders the dart more susceptible to deflection by wind, branches, and stochastic drift in the trajectory as the oscillating dart is released from the atlatl. Increasing projectilepoint mass could therefore be expected to counter such instability (Christenson 1986; Hughes 1998) potentially offsetting accuracy losses due to decreasing dart mass that might be expected with diminishing dart length.

The dart momentum and accuracy hypotheses lead us to expect that larger and heavier dart points should exhibit greater penetration and accuracy than lighter dart points. The primary goal of this study is to test these expectations experimentally. We focus on techno-functional hypotheses not to diminish the alternative hypotheses outlined earlier nor any hypotheses that we may have failed to consider. Rather, our focus reflects a small, tractable contribution toward a larger effort of evaluating competing models to explain increasing projectile-point size.

A related secondary goal of our analysis is to gain insight into the use and manufacturing costs of camelid bone atlatls. Although such implements are known from a few rare Atacama specimens (Figure 3B), how the unconventional forms work remains unknown because, to our knowledge, their use has never been observed ethnographically or experimentally. Curiously, the archaeologically observed bone atlatls are curved in the opposite direction from typical atlatls observed elsewhere in the Americas and used by atlatl enthusiasts today. Such atlatls are typically flat or arc upward such that the ends bow toward the dart when the two components are engaged. The Andean bone atlatls, however, bow in the opposite direction such that the atlatl ends arc away from the dart when engaged. What is particularly peculiar about this geometry is that it would seem to preclude one-hand operation. Qualitative examination of images of the archaeological specimens seem to suggest that it is impossible to simultaneously engage the atlatl hook with the butt end of the dart while supporting the dart shaft with the throwing hand fingers, as is the typical atlatl throwing style. The counter-arcing form of the bone atlatl would seem to prevent such an arrangement. We therefore hypothesize that the distinct geometry of camelid radioulna atlatls would have entailed a distinct throwing technique that required twohanded operation, with the nonthrowing hand used to support the dart shaft before launch.

In terms of production costs, we expect relatively long manufacturing times, because bone is denser than wood and bone grease would tend to clog the pores of sanding implementsa problem that is less likely to be experienced with wood. We suppose that such high production costs would have been absorbed out of necessity under conditions of wood scarcity. 


\section{Materials and Methods}

This study used replicated camelid bone atlatls, wood darts, and flaked-stone projectile points in ballistic trials to evaluate production costs and performance characteristics under conditions of variable projectile-point size. There have been at least two other experimental Andean atlatl studies, both of which examined different questions than we did. Martínez and Aschero (2003) examined projectile-point breakage patterns, whereas Martínez and Funes (2011) examined the performance of beveled hafting systems and dart fletching. We are particularly interested in understanding how projectile size affects penetration depth and accuracy. We opted for a relatively naturalistic experimental approach that would allow us to gain broad insights into production and performance while evaluating the model expectations. We acknowledge the importance of more controlled experiments, but our approach offers a critical first step for broadly understanding an atlatl system that has, to our knowledge, not been used in several millennia. Such semistructured experimentation should intelligently guide more focused experiments conducted at a later time. To the extent possible, aboriginal tools were used to create the atlatl, darts, and projectile points.

Although vicuña radioulna would have been used in the Archaic period, we used alpaca radioulna for our experiment for two reasons. First, whereas vicuña are a protected species, alpaca are common farm animals, making alpaca bone readily accessible. Second, this substitution is likely to be of little consequence for the experimental design, given that the two taxa are essentially the same species: vicuña are the wild ancestor of the alpaca, and their bone structures are likely isomorphic (Bonavia 2008; Pacheco Torres et al. 1979). We used thick tabular pieces of sandstone from the German Rancho Formation in California to grind the superior surface of each alpaca bone. We ground the bone until the medullary cavity was exposed as observed in archaeological specimens (see Figure 3C). Then, we used a thin piece of sandstone with an acute edge for more detailed shaping of the spur.

We used heat-treated chert for projectile-point production (Figure 4). Chert was commonly used in the Lake Titicaca Basin because of its abundance and accessibility (Haas et al. 2017), and Archaic period Titicaca Basin groups heattreated lithic material to facilitate flaking. Our points were manufactured from heat-treated Keokuk chert, which was purchased from a US material supplier. We modeled our replicas after Altiplano 3D-style points (Klink and Aldenderfer 2005). We chose this form because of its relatively simple lanceolate shape and the fact that it was used over a long time span across the Middle and Late Archaic periods. Six projectile points of varying size were manufactured with the goal of uniformly spanning the range of sizes in archaeological samples.

Because Andean dart forms and materials are currently unknown from the archaeological record, some speculation was required for the design of the experimental dart. We suspected that queñual (Polylepis sp.) would have been the major material for dart construction. Unfortunately, we were unable to identify suitable queñual shafts during limited, informal searches on the Altiplano. We therefore used material that is readily accessible to us in California. We constructed the dart main shaft from a branch of seep willow (Baccharis salicifolia), which is a species that produces long, straight branches. The shaft was steam-straightened after harvesting and subsequently bundled with other branches and dried in the shade for three weeks.

Because of resource scarcity in the Andean highlands, and given the documentation of atlatl foreshafts elsewhere in the Andes (de Souza 2011; Martínez and Funes 2011; Núñez et al. 2006) and in the Americas (e.g., Frison 1968; Harrington 1924; Lahren and Bonnichsen 1974; Lindsay 1968), we speculated that Altiplano Archaic populations likely manufactured dart foreshafts. We therefore manufactured multiple foreshafts and a single mainshaft. The use of a single mainshaft with multiple foreshafts not only replicated archaeological dart design but also provided a degree of experimental control by holding the main shaft constant for all throws. Six foreshafts of identical mass were made of toyon (Heteromeles arbutifolia) wood. The foreshaft bark was removed when green, and the ends of the foreshaft preforms were coated with paraffin wax to prevent wood checking. We cut 


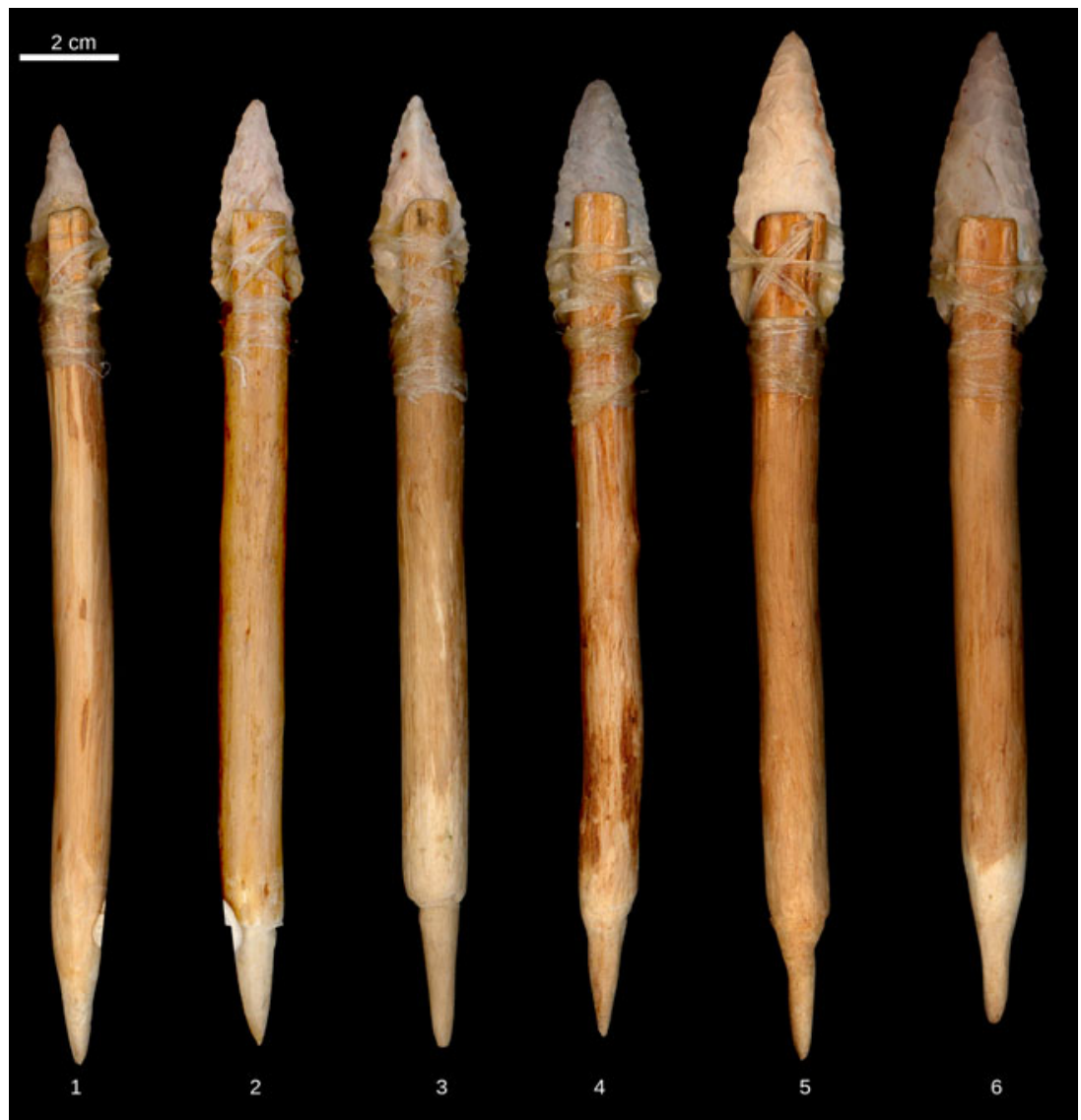

Figure 4. Experimental projectile points and foreshafts used in this study (photograph by Caleb Chen). (Color online)

projectile-point haft slots into the foreshafts using a groove-and-snap technique (Cosgrove 1947:52-54; Whittaker 1994) and shaped the proximal ends of the foreshafts by grinding them on a slab of sandstone. Thicker foreshafts were slightly shortened to equalize mass for all the foreshafts.

Hide glue and alpaca sinew were used to haft points onto the foreshafts and fletch the mainshaft. Our attempt at making alpaca hide glue failed. We therefore used Titebond liquid hide glue. Dried alpaca leg sinew was processed using a hammerstone with a hammer-anvil technique and subsequently hydrated by chewing prior to application to the foreshafts and main shaft. Turkey feather fletching and projectile points were bound to the shafts with the sinew and hide glue.

For the ballistic target, a ballistic gelatin mixture of 4,990 g gelatin and $43 \mathrm{~L}$ water was poured into a plywood mold, yielding a gel block with dimensions $40.5 \times 30 \times 21.5 \mathrm{~cm}$. Paper bullseye targets with direction and distance markers were placed on the anterior surface of the gel block to measure accuracy.

The first author used one of the experimental alpaca bone atlatls to fire darts into the ballistic gel block at a distance of $5 \mathrm{~m}$ (Figure 3D). We randomized projectile-point firing order to control for potential effects of user improvement or material changes (e.g., implement wear or target degradation) over time. Penetration depths were recorded by marking the dart foreshafts in the gel block and measuring from the marked area to the point tip. Accuracy was recorded as distance from the center of the target, which was demarcated with a paper bullseye target overlaying the ballistic gel block. Because complete misses were frequent, we also recorded miss 
frequency for use in calculating hit:miss ratios as a secondary measure of accuracy.

We performed two sets of trials, each on separate days. Opposite sides of the gel block were used on days one and two to minimize chances of redundant hits. Each projectile point was fired until the point or foreshaft failed.

We used linear regression to evaluate the effect of point mass on penetration depth and accuracy. This provided a preliminary visualization and assessment of the data. To account for random effects that result from the repeated use of projectile points (i.e., each shot is not an entirely independent event), we also performed linear regression with dependent variables averaged by projectile point. Finally, we performed linear fixed-effects modeling with projectilepoint mass means as the fixed effect and projectile-point number as the random effect. All computation was performed in $\mathrm{R}$ statistical computing language using linear modeling base routines ( $\mathrm{R}$ Core Team 2020), the lme4 package for fixed-effects analysis (Bates et al. 2015), and the lmerTest package (Kuznetsova et al. 2017) for generating fixed-effects model $p$-values. Because our analytical procedure is largely naturalistic so as to gain broad insights into the technology, we take a rather liberal approach to assessing statistical significance, seeking tentative relationships that merit further consideration with more controlled experimentation. We therefore consider $p$-values of less than 0.1 to be suggestive of statistically significant relationships.

\section{Results}

We manufactured two radioulna atlatls in 5.5 and 3.3 hours (Table 1). The reduced time for the second atlatl reflects improvements in technique. In particular, we realized that clogging of the sandstone pores could be minimized by scraping grease from the bone with a flake. Counter to expectations, we experienced surprisingly short production times. We also learned that the medullary cavity of the radioulna bone created a convenient resting channel for the dart. The channel stabilized the dart, allowing its butt end to articulate with the atlatl hook as the thrower used the fingers of the throwing hand
Table 1. Atlatl Production Times.

\begin{tabular}{|c|c|c|c|c|c|}
\hline \multirow{2}{*}{$\begin{array}{l}\text { Atlatl } \\
\text { Component }\end{array}$} & \multicolumn{3}{|c|}{$\begin{array}{l}\text { Manufacturing } \\
\text { Time (hrs) }\end{array}$} & \multirow[b]{2}{*}{$n$} & \multirow[b]{2}{*}{ Notes } \\
\hline & $\min$. & $\max$. & mean & & \\
\hline $\begin{array}{l}\text { Projectile } \\
\text { points }\end{array}$ & 0.6 & 2.1 & 1.4 & 6 & \\
\hline Foreshafts & 1.2 & 3.1 & 2.2 & 6 & $\begin{array}{c}\text { Shave bark, create } \\
\text { haft slot, haft } \\
\text { projectile point }\end{array}$ \\
\hline Mainshaft & 4.3 & 4.3 & 4.3 & 1 & $\begin{array}{l}\text { Steam straightening } \\
\text { shaft, shave bark, } \\
\text { fletch }\end{array}$ \\
\hline Atlatl & 3.3 & 5.5 & 4.4 & 2 & \\
\hline Total & 9.5 & 15.0 & 12.2 & & $\begin{array}{l}\text { Assuming one of } \\
\text { each component }\end{array}$ \\
\hline
\end{tabular}

to support the shaft (see Figure 3D and 3E). In other words, contrary to our hypothesis of a two-hand throwing style, we learned that the radioulna bone atlatl can be operated with one hand.

Experimental projectile-point mass including foreshafts ranged from 17.9 to $30.9 \mathrm{~g}$. Final masses for assembled projectile foreshafts 4 and 5 were the same after hafting. The dart main shaft weighed $75.6 \mathrm{~g}$ and was used for all trials. Given our relative inexperience in producing such atlatl systems, we use our minimal manufacturing times to estimate a manufacturing time of approximately 9.5 hours for Andean hunter-gatherers (Table 1). Our results make clear that, given all of the right materials, an effective camelid bone atlatl can be produced in a single day. Note that these estimates only include active production times and do not include material drying times.

The experiment resulted in 136 shots: 48 hits and 88 misses (Table 2). We used hit:miss data, aggregated by projectile point $(n=6)$, to assess the effects of mass on accuracy. Furthermore, the 48 hits were used to assess accuracy as measured by distance from the target center. Not all target hits contacted the gel block and thus not all provided penetration depth data. We recorded 34 depth measurements.

The raw penetration depth data $(n=34)$ reveal a statistically significant negative relationship with point mass at an estimated rate of $-0.25 \pm$ $0.09 \mathrm{~cm} / \mathrm{g}(p=0.01)$ - $\mathrm{a}$ trend that is opposite to 
Table 2. Ballistic Test Data.

\begin{tabular}{|c|c|c|c|c|c|c|}
\hline Trial Day & Point ID & Mass $(\mathrm{g})^{*}$ & Depth (cm) & Direction (degrees) & Inaccuracy $(\mathrm{cm})^{* *}$ & Notes \\
\hline 1 & 1 & 17.86 & NA & 255 & 19.6 & Hit paper, missed gel block \\
\hline 1 & 1 & 17.86 & 5.5 & 40 & 6.3 & \\
\hline 1 & 1 & 17.86 & 1.1 & 300 & 13.6 & Foreshaft dislodged \\
\hline 1 & 1 & 17.86 & 6.8 & 280 & 14.8 & \\
\hline 1 & 1 & 17.86 & 5.8 & 0 & 9.8 & \\
\hline 2 & 1 & 17.86 & NA & 65 & 23.9 & Hit paper, missed gel block \\
\hline 2 & 1 & 17.86 & 7.4 & 90 & 11.7 & \\
\hline 2 & 1 & 17.86 & NA & 80 & 20.5 & Hit paper, missed gel block \\
\hline 1 & 2 & 20.98 & NA & 270 & 4.5 & Hit paper, missed gel block \\
\hline 1 & 2 & 20.98 & NA & 345 & 22.5 & Hit paper, missed gel block \\
\hline 1 & 2 & 20.98 & NA & 58 & 21.5 & Hit paper, missed gel block \\
\hline 1 & 2 & 20.98 & NA & 308 & 12.0 & Hit paper, missed gel block \\
\hline 1 & 2 & 20.98 & 6.1 & 310 & 18.0 & \\
\hline 1 & 2 & 20.98 & 4.8 & 65 & 15.0 & \\
\hline 1 & 2 & 20.98 & NA & 227 & 13.0 & Hit paper, missed gel block \\
\hline 1 & 2 & 20.98 & NA & 135 & 18.5 & Hit paper, missed gel block \\
\hline 2 & 2 & 20.98 & 5.5 & 90 & 14.2 & \\
\hline 1 & 3 & 24.10 & 2.6 & 290 & 20.9 & \\
\hline 1 & 3 & 24.10 & 1.6 & 130 & 10.7 & \\
\hline 1 & 3 & 24.10 & 5.5 & 303 & 5.4 & \\
\hline 1 & 3 & 24.10 & NA & 270 & 21.4 & Hit paper, missed gel block \\
\hline 1 & 3 & 24.10 & 6.2 & 285 & 13.1 & \\
\hline 1 & 3 & 24.10 & 5.2 & 40 & 10.2 & \\
\hline 1 & 3 & 24.10 & NA & 290 & 22.1 & Hit paper, missed gel block \\
\hline 2 & 3 & 24.10 & NA & 50 & 21.1 & Hit paper, missed gel block \\
\hline 2 & 3 & 24.10 & 1.4 & 303 & 16.2 & \\
\hline 2 & 3 & 24.10 & 4.0 & 0 & 6.3 & \\
\hline 2 & 3 & 24.10 & 1.5 & 263 & 18.8 & \\
\hline 2 & 3 & 24.10 & 1.7 & 228 & 19.2 & \\
\hline 2 & 3 & 24.10 & 0.9 & 25 & 13.2 & \\
\hline 2 & 3 & 24.10 & 2.3 & 80 & 16.8 & \\
\hline 2 & 3 & 24.10 & NA & 50 & 21.1 & Hit paper, missed gel block \\
\hline 1 & 4 & 26.93 & 0.7 & 7 & 12.4 & \\
\hline 1 & 4 & 26.93 & 0.9 & 135 & 5.8 & \\
\hline 1 & 4 & 26.93 & 4.9 & 323 & 14.4 & \\
\hline 1 & 4 & 26.93 & 1.3 & 270 & 10.6 & \\
\hline 1 & 4 & 26.93 & 1.5 & 15 & 2.0 & \\
\hline 2 & 4 & 26.93 & 2.2 & 15 & 7.6 & \\
\hline 2 & 4 & 26.93 & 3.3 & 80 & 19.1 & \\
\hline 2 & 4 & 26.93 & 6.0 & 55 & 15.8 & \\
\hline 2 & 4 & 26.93 & 1.2 & 228 & 19.1 & \\
\hline 2 & 4 & 26.93 & 2.1 & 293 & 21.0 & \\
\hline 2 & 4 & 26.93 & NA & 0 & 14.2 & Hit paper, missed gel block \\
\hline 1 & 5 & 26.93 & 0.9 & 300 & 8.6 & \\
\hline 1 & 5 & 26.93 & 4.1 & 207 & 16.9 & \\
\hline 1 & 6 & 30.9 & 1.2 & 190 & 5.8 & \\
\hline 2 & 6 & 30.9 & 3.6 & 333 & 10.1 & \\
\hline 2 & 6 & 30.9 & 5.4 & 350 & 12.5 & \\
\hline
\end{tabular}

the predicted relationship (Figure 5A). When averaging depth values by projectile point $(n=6)$ to control for autocorrelation, a statistically significant negative relationship of $-0.23 \pm 0.09$ $\mathrm{cm} / \mathrm{g}$ is maintained, although it is slightly diminished ( $p=0.07$, Figure 5B). Fixed-effects analysis confirms a statistically significant negative relationship of $-0.25 \pm 0.09 \mathrm{~cm} / \mathrm{g}(p=0.06)$. 
A

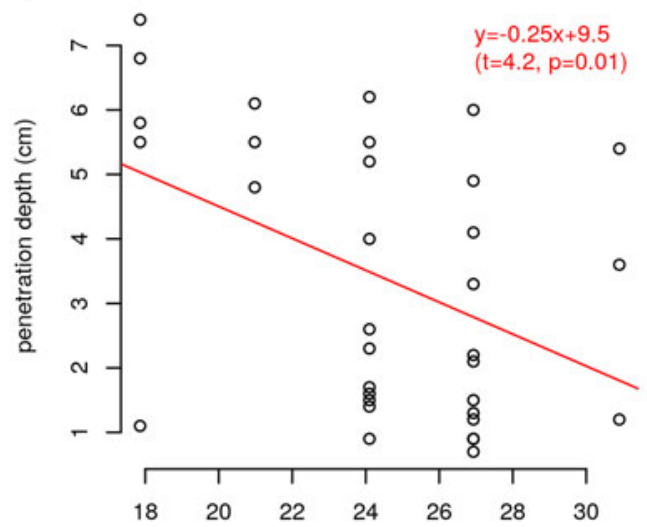

C

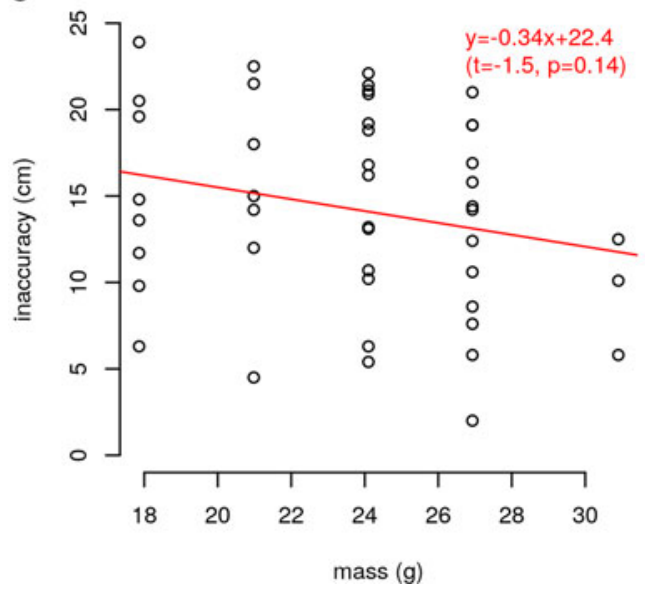

B

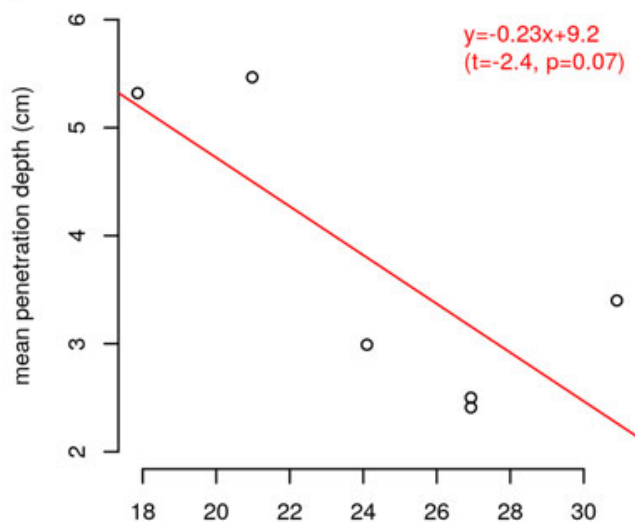

D

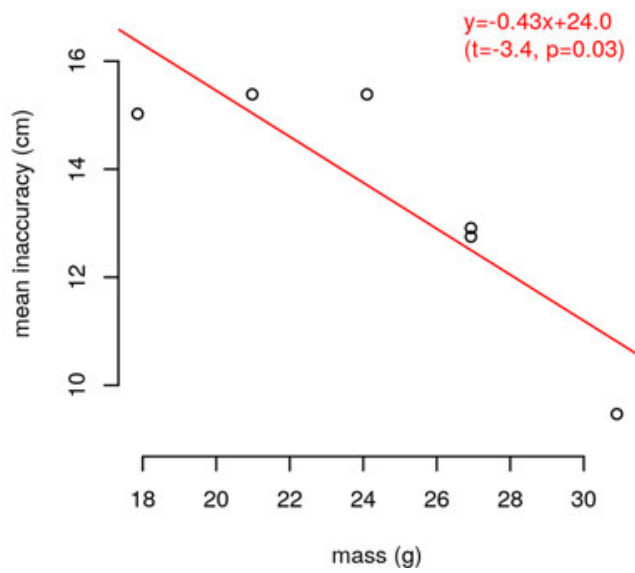

Figure 5. Regression test results. (A) Raw data $(n=34)$ showing statistically significant negative effect of mass on penetration depth, counter to expectation; (B) data averaged by projectile point $(n=6)$ showing statistically significant negative effect of mass on penetration depth; (C) raw data $(n=45)$ showing statistically nonsignificant negative effect of mass on inaccuracy or distance from center of target; (D) data averaged by projectile point $(n=6)$ showing statistically significant negative effect of mass on inaccuracy.

For accuracy assessment, raw inaccuracy measurements $(n=45)$ fail to support the predicted negative relationship with point mass (Figure 5C), though the observed relationship is negative and marginally nonsignificant $(p=$ $0.14)$. In contrast, averaging the inaccuracy values by projectile point $(n=6)$ to control for autocorrelation reveals a statistically significant negative trend of $-0.43 \pm 0.12 \mathrm{~cm} / \mathrm{g} \quad(p=0.03$; Figure 5D). However, fixed-effects analysis reveals the model fit to be singular due to the small sample size, suggesting no statistically significant relationship. The hit percentage analysis is consistent with this finding, showing no statistically significant relationship between mass and hit percentage for the six points (Table $3 ; p=0.58$ ).

\section{Discussion}

The finding of a negative relationship between projectile-point mass and penetration depth is consistent with the recent analysis by Mika and colleagues (2020), which observed this trend in a more controlled experiment using bow-and-arrow technology. They found that smaller points outperformed larger points in penetration tests when draw weight was held constant. In similar controlled experiments testing projectile-point 
Table 3. Hit:Miss Data Summary.

\begin{tabular}{|c|c|c|c|c|c|c|}
\hline Point & $\begin{array}{c}\text { Point } \\
\text { Mass } \\
(\mathrm{g})\end{array}$ & $\begin{array}{l}\text { Foreshaft } \\
\text { Mass }(\mathrm{g})^{*}\end{array}$ & Hits & Misses & $\begin{array}{c}\text { Total } \\
\text { Throws }\end{array}$ & Hit $\%$ \\
\hline 1 & 5.95 & 17.86 & 8 & 14 & 22 & 36 \\
\hline 2 & 9.07 & 20.98 & 9 & 15 & 24 & 38 \\
\hline 3 & 12.19 & 24.10 & 15 & 20 & 35 & 43 \\
\hline 4 & 15.02 & 26.93 & 11 & 26 & 37 & 30 \\
\hline 5 & 15.02 & 26.93 & 2 & 8 & 10 & 25 \\
\hline 6 & 18.99 & 30.90 & 3 & 5 & 8 & 38 \\
\hline Total & & & 48 & 88 & 136 & \\
\hline
\end{tabular}

* includes point

penetration, Eren and colleagues (2020) and Sitton and colleagues (2020) also observed a negative relationship between projectile-point size and penetration. It would appear that lost velocity or increased drag, which results from size increase, outweighs any potential gains in momentum, thus diminishing penetration depth with increasing point size. Alternatively, increased dart mass may reduce dart velocity, thus reducing net kinetic energy, net dart momentum, and penetration of larger projectiles.

The results of our accuracy analysis were less clear. The linear model on the raw data, fixed-effects model, and hit:miss analyses showed no statistically significant relationship between accuracy and point mass. In contrast, the linear model on projectile-point-averaged accuracy data revealed a statistically significant negative relationship. This observation may hint at a latent effect masked by other variables in our relatively uncontrolled experiment. More trials would have been useful for resolving the analytical ambiguity, but unfortunately our experimental equipment was exhausted, preventing additional data collection. Here we see the merit of the naturalistic experimental design in identifying an area in need of more focused investigation while also highlighting its limits in generating conclusive results for specific relationships.

Given that projectile-point mass affects accuracy and penetration, how would small differences in mass affect these variables? Would they appreciably affect hunting success rates? To begin to answer these questions, we consider the magnitude of effects observed in our analyses. In our point-aggregate analysis, we observed that accuracy increased at a rate of $4.3 \mathrm{~cm}$ for each gram of increase in projectile point mass. Recognizing that those results are statistically insignificant, we nonetheless wish to consider the extent to which the tentative trends matter and additional research is justified. First, consider that the size of the kill zone of an ungulate is approximately $30 \mathrm{~cm}$ in diameter (O'Connor 1970; Tomka 2013), which gives a radius of $15 \mathrm{~cm}$. Second, consider that our experiment observed an average inaccuracy of $16 \mathrm{~cm}$ with an $18 \mathrm{~g}$ dart (with foreshaft) at a distance of $5 \mathrm{~m}$ (see Figure 5D). This means that roughly half of all shots would land inside the kill zone. When the dart mass was increased to $30 \mathrm{~g}$, average inaccuracy dropped $60 \%$ to $10 \mathrm{~cm}$. Thus, roughly threefourths of all shots would land inside the kill zone with the larger dart point. Of course, we should not make too much of these particular numbers, given that we are rather inexperienced atlatlists. Collecting additional accuracy data in future trials with experienced atlatlists (sensu Grund 2017) could potentially lead to more precise accuracy estimates. Nonetheless, our numbers are instructive in showing that small differences in projectile-point mass may have accuracy effects of sufficient magnitude to appreciably affect hunting success. If so, under certain economic conditions, we should expect strong selection for larger points, given the ostensible performance gains of increasing point size.

Our observations on penetration depths point in the opposite direction. We observed that large points with a mass of $30 \mathrm{~g}$ could be expected to penetrate to a depth of $2 \mathrm{~cm}$. By decreasing point size to $18 \mathrm{~g}$, expected penetration depth more than doubles to approximately $5 \mathrm{~cm}$. If we assume that an ungulate kill zone is spherical in shape with a radius of $15 \mathrm{~cm}$, we should expect that, near the margins of the kill zone, the depth to projectile-point contact would be $8.5 \mathrm{~cm}$ greater than at the center. Four $\mathrm{cm}$ of increased penetration depth, which is roughly half that distance, could therefore be expected to make a substantial difference between a projectile point entering the kill zone or not in a high proportion of on-target shots. We should therefore expect selection for small points in the interest of increasing penetration. 
Perhaps most interestingly, the fact that accuracy and penetration respond to projectile-point mass in opposite directions - at least potentially so- offers a hypothetical explanation for why archaeologically observed projectile points tend to exhibit modal sizes. It may be that those modes reflect optimal trade-offs between accuracy and penetration as a function of point mass, which Christenson (1986) and Hughes (1998) have previously suggested. We might further expect different optima for atlatl and bow-and-arrow technology, given the differences in firing mechanisms. Indeed, modal size differences between atlatl dart points and arrow points are well documented (Christenson 1986; Hildebrandt and King 2012; Shott 1997; Thomas 1978).

This potential trade-off leads us to consider an updated technological hypothesis for increasing projectile-point size on the Andean Altiplano. As Andean populations grew, increasing raw material competition would have diminished access to high-quality dart shafts of appropriate length, which would have reduced dart mass and compromised dart accuracy. Atlatl producers would have offset such accuracy losses by increasing projectile-point mass, at least up to the point that resultant losses in dart penetration overwhelmed the gains in accuracy. Additional theoretical and experimental work aimed at validating the accuracy-mass relationship and identifying the statistical structure of theoretical point-size optima for different projectile technologies would be invaluable.

\section{Summary and Conclusion}

This study began with the observation of an unusual case of projectile-point enlargement from the Early Archaic through the Late Archaic periods on the Andean Altiplano. We presented a series of candidate explanations, including dartpenetration and dart-accuracy hypotheses. We tested expectations derived from these two hypotheses, performing atlatl test trials with variably sized projectile points. We opted for a relatively naturalistic experimental design to gain broad insights into the production and use dynamics of bone atlatls, which are known from Andean archaeology. Following this naturalistic approach rather than a more controlled experimental design has come at some cost to analytical certainty. Nonetheless, several clear qualitative observations were made, and at least one quantitative signal rose above the noise.

First, we found that a camelid radioulna atlatl system can be produced relatively quickly -in less than a single day given access to suitable materials. Production costs are thus surprisingly low, counter to our initial expectations. We further observed that the medullary cavity of the radioulna is a key morphological feature that (1) overcomes the atlatl's unusual counter-arcing geometry and (2) creates a convenient resting channel for stabilizing the dart before launch. Second, we confidently rejected our prediction that heavier points penetrate deeper than lighter ones. In fact, the results indicated that increasing projectile-point mass reduced dart penetration. Third, we tentatively concluded that mass does not significantly affect accuracy, but we were unable to rule out a potential relationship given that one of our analyses produced a statistically significant result, suggesting a potentially latent effect.

These observations lead us to update our technological model for increasing projectilepoint size on the Altiplano. We consider that projectile-point size reflects a trade-off between penetration and accuracy. Increasing projectilepoint size in the Altiplano Archaic may reflect attempts to compensate for diminishing accuracy as the raw materials for dart production became increasingly scarce in a resource-limited landscape. We underscore that our working model for projectile-point size increase is provisionalcontingent on one sound premise and another admittedly ambiguous one.

Whether or not the posited relationship between mass and accuracy proves valid, alternative models also require consideration. We further recognize that the models are not mutually exclusive. Recall that one hypothesis considered earlier envisions that population migration drove changes in projectile-point size. Another posits that point enlargement on the Altiplano occurred as a result of increasing territoriality and violence. Readers will certainly envision other potential explanations. Tests derived from the various hypotheses and drawing on various lines of archaeological evidence are needed. 
For example, the migration model predicts changes in the genetic structure of Altiplano Archaic populations. The threat-display model predicts increasing interpersonal violence rates over time and increasingly localized isotopic signatures in human skeletal remains. We are confident that such multifaceted analytical approaches will ultimately resolve the question of why projectile-point size increased on the Andean Altiplano and perhaps other times and places. Such basic insights into allometric phenomena will contribute to our understanding of culture change in human societies.

Acknowledgments. Virginia Incacoña, Juan Incacoña, and Mateo Incacoña (Community of Totorani, Puno, Peru) helped obtain the camelid bone for this experiment. Kevin Smith (UC Davis) provided consultation on atlatl production. Damien Caillaud (UC Davis) provided statistical consultation. Trenton Yackzan, Caleb Weeks, Thomas Stull, and Adam Cooperman (Sudwerk Brewery) and Gregory Wada (UC Davis) assisted with refrigeration of the ballistic gel target. Ondrej Uma assisted with constructing the plywood ballistic gel mold for this study. Freeman George (UC Davis) assisted with the experiments. Christyann Darwent (UC Davis) provided lab space. Nicolas Zwyns (UC Davis) provided flintknapping materials and advice. Sara Watson (UC Davis) assisted with efforts to heat-treat California cherts, although those materials were not ultimately used in this study. UC Davis Department of Anthropology Undergraduate Research Program provided financial support. Members of the UC Davis Forager Complexity $\mathrm{Lab}$ group and four anonymous reviewers provided valuable feedback on this study. Author contributions: RH and $\mathrm{CC}$ designed the research; $\mathrm{CC}$ replicated the tools and performed the experiments; $\mathrm{RH}$ and $\mathrm{CC}$ performed the statistical analysis; LF and RH analyzed the archaeological projectile points; and $\mathrm{CC}$ and $\mathrm{RH}$ wrote the article. The authors declare no competing interests.

Data Availability Statement. All data to support our analysis and make it reproducible are provided in the article.

\section{References Cited}

Bates, Douglas, Martin Mächler, Ben Bolker, and Steve Walker

2015 Fitting Linear Mixed-Effects Models Using lme4. Journal of Statistical Software 67:1-48.

Baugh, Richard A.

1998 Atlatl Dynamics. Lithic Technology 23:31-41.

Bettinger, Robert L., and Jelmer Eerkens

1999 Point Typologies, Cultural Transmission, and the Spread of Bow-and-Arrow Technology in the Prehistoric Great Basin. American Antiquity 64:231-242.

Bonavia, Duccio

2008 The South American Camelids. Cotsen Institute of Archaeology, University of California, Los Angeles.
Christenson, Andrew L.

1986 Projectile Point Size and Projectile Aerodynamics: An Exploratory Study. Plains Anthropologist 31:109-128.

Cosgrove, Cornelius B.

1947 Caves of the Upper Gila and Hueco Areas in New Mexico and Texas. Papers Vol. 24, No. 2. Peabody Museum of American Archaeology and Ethnology, Cambridge, Massachusetts.

Craig, Nathan

2011 Cultural Dynamics, Climate, and Landscape in the South-Central Andes during the Mid-Late Holocene: A Consideration of Two Socio-Natural Perspectives. Chungara 43(especial):367-391.

Craig, Nathan M., Mark S. Aldenderfer, Paul A. Baker, and Catherine A. Rigsby

2010 Terminal Archaic Settlement Pattern and Land Cover Change in the Rio Ilave, Southwestern Lake Titicaca Basin, Peru. In The Archaeology of Anthropogenic Environments, edited by Rebecca M. Dean, pp. 35-53. Center for Archaeological Investigations, Southern Illinois University, Carbondale.

Crivelli, Carlos, James A. Russell, Sergio Jarillo, and JoséMiguel Fernández-Dols

2016 The Fear Gasping Face as a Threat Display in a Melanesian Society. PNAS 113:12403-12407.

Cross, Scott L., Paul A. Baker, Geoffrey O. Seltzer, Sherilyn C. Fritz, and Robert B. Dunbar

2001 Late Quaternary Climate and Hydrology of Tropical South America Inferred from an Isotopic and Chemical Model of Lake Titicaca, Bolivia and Peru. Quaternary Research 56:1-95.

de Souza, Patricio

2004 Tecnologías de proyectil durante los períodos Arcaico y Formativo en el loa superior (Norte de Chile): A partir del análisis de puntas líticas. Chungara 36:61-76.

2011 Sistemas de proyectiles y cambio social durante el tránsito Arcaico Tardío-Formativo Temprano de la Puna de Atacama. In Temporalidad, interacción y dinamismo cultural: La búsqueda del hombre: Homenaje al Profesor Lautaro Núñez Atencio, edited by André Hubert, pp. 201-246. Universidad Católica del Norte, Antofagasta, Chile.

Ellis, Christopher J.

1997 Factors Influencing the Use of Stone Projectile Tips. In Projectile Technology, edited by Heidi Knecht, pp. 37-74. Plenum Press, New York.

Eren, Metin I., Brett Story, Alyssa Perrone, Michelle Bebber, Marcus Hamilton, Robert Walker, and Briggs Buchanan

2020 North American Clovis Point Form and Performance: An Experimental Assessment of Penetration Depth. Lithic Technology 45:263-282.

Fernández Distel, Alicia A.

1986 Las Cuevas de Huachichocana: Su posición dentro del Precerámico con agricultura incipiente del noroeste Argentino. Beiträge zur Allgemeinen und Vergleichenden Archäologie 8:353-430.

Frison, George

1968 Daugherty Cave, Wyoming. Plains Anthropologist 13:253-295.

Gayo, Eugenia M., Claudio Latorre, and Calogero M. Santoro 2015 Timing of Occupation and Regional Settlement Patterns Revealed by Time-Series Analyses of an Archaeological Radiocarbon Database for the South-Central Andes $\left(16^{\circ}-25^{\circ} \mathrm{S}\right)$. Quaternary International 356:4-14. 
Grund, Brigid Sky

2017 Behavioral Ecology, Technology, and the Organization of Labor: How a Shift from Spear Thrower to Self Bow Exacerbates Social Disparities. American Anthropologist 119:104-119.

Haas, Randall, Cynthia J. Klink, Greg J. Maggard, and Mark S. Aldenderfer

2015 Settlement-Size Scaling among Prehistoric HunterGatherer Settlement Systems in the New World. PLoS ONE 10(11):e0140127.

Haas, Randall, Ioana C. Stefanescu, Alexander GarciaPutnam, Mark S. Aldenderfer, Mark T. Clementz, Melissa S. Murphy, Carlos Viviano Llave, and James T. Watson

2017 Humans Permanently Occupied the Andean Highlands by at Least $7 \mathrm{ka}$. Royal Society Open Science 4(6): 170331.

Haas, Randall, and Carlos Viviano Llave

2015 Hunter-Gatherers on the Eve of Agriculture: Investigations at Soro Mik'aya Patjxa, Lake Titicaca Basin, Peru, 8000-6700 BP. Antiquity 89:1297-1312.

Haas, Randall, James Watson, Tammy Buonasera, John Southon, Jennifer C. Chen, Sarah Noe, Kevin Smith, et al.

2020 Female Hunters of the Early Americas. Science Advances 6(45):eabd0310.

Hamilton, Marcus J., and Briggs Buchanan

2009 The Accumulation of Stochastic Copying Errors Causes Drift in Culturally Transmitted Technologies: Quantifying Clovis Evolutionary Dynamics. Journal of Anthropological Archaeology 28:55-69.

Harrington, Mark R.

1924 The Ozark Bluff-Dwellers. American Anthropologist 26:1-21.

Hildebrandt, William R., and Jerome H. King

2012 Distinguishing between Darts and Arrows in the Archaeological Record: Implications for Technological Change in the American West. American Antiquity 77:789-799.

Hostnig, Rainer

2018 Representaciones humanas y composiciones escénicas en pinturas rupestres de Carabaya, Puno, Perú. Rupestreweb. http://www.rupestreweb.info/antropocarabaya. html, accessed September 24, 2021.

Hughes, Susan S.

1998 Getting to the Point: Evolutionary Change in Prehistoric Weaponry. Journal of Archaeological Method and Theory 5:345-408.

Klink, Cynthia J.

2005 Archaic Period Research in the Rio Huenque Valley, Peru. In Advances in Titicaca Basin Archaeology-1, edited by Charles Stanish, Amanda B. Cohen, and Mark S. Aldenderfer, pp. 13-24. Cotsen Institute of Archaeology, University of California, Los Angeles.

Klink, Cynthia J., and Mark S. Aldenderfer

2005 A Projectile Point Chronology for the South-Central Andean Highlands. In Advances in Titicaca Basin Archaeology -1 , edited by Charles Stanish, Amanda B. Cohen, and Mark S. Aldenderfer, pp. 25-54. Cotsen Institute of Archaeology, University of California, Los Angeles.

Kuznetsova, Alexandra, Per B. Brockhoff, and Rune H. B. Christensen

2017 lmerTest Package: Tests in Linear Mixed Effects Models. Journal of Statistical Software 82:1-26.

Ladich, Friedrich

1990 Vocalization during Agonistic Behaviour in Cottus gobio L. (Cottidae): An Acoustic Threat Display. Ethology 84:193-201.

Lahren, Larry, and Robson Bonnichsen

1974 Bone Foreshafts from a Clovis Burial in Southwestern Montana. Science 186:147-150.

Lindsay, Alexander J.

1968 Survey and Excavations North and East of Navajo Mountain, Utah, 1959-1962. Northern Arizona Society of Science and Art, Flagstaff.

Marsh, Erik J.

2014 The Emergence of Agropastoralism: Accelerated Ecocultural Change on the Andean Altiplano, 3540 3120 cal BP. Environmental Archaeology 20:13-29.

Martínez, Jorge G., and Carlos A. Aschero

2003 Proyectiles experimentales: Inca Cueva 7 como caso de estudio. Cuadernos de la Facultad de Humanidades y Ciencias Sociales-Universidad Nacional de Jujuy 20:351-364.

Martínez, Jorge G., and Jorge A. Funes Coronel

2011 Confección y performance experimental de proyectiles arqueológicos del Ámbito Puneño. In Armas prehispánicas: Múltiples enfoques para su estudio en Sudamérica, edited by J. G. Martínez and D. L. Bozzuto, pp. 37-56. Fundación de Historia Natural Félix de Azara, Buenos Aires.

Mika, Anna, Kat Flood, James D. Norris, Michael Wilson, Alastair Key, Briggs Buchanan, Brian Redmond, et al.

2020 Miniaturization Optimized Weapon Killing Power during the Social Stress of Late Precontact North America (AD 600-1600). PLoS ONE 15(3):e0230348.

Muscio, Hernán J., and Gabriel E. J. López

2016 Radiocarbon Dates and Anthropogenic Signal in the South-Central Andes (12,500-600 cal. years BP). Journal of Archaeological Science 65:93-102.

Núñez, Lautaro, Isabel Cartajena Fasting, Carlos Carrasco G., Patricio de Souza H., and Martin Grosjean

2006 Emergencia de comunidades pastoralistas formativas en el sureste de la Puna de Atacama. Estudios Atacameños 32:93-117.

O'Connor, Jack

1970 The Hunting Rifle. Winchester Press, New York.

Pacheco Torres, Victor R., Alfredo Altamirano Enciso, and Enma Gurra Porras

1979 The Osteology of South American Camelids, Vol. 3. Cotsen Institute of Archaeology, University of California, Los Angeles.

Pargeter, Justin and John Shea

2019 Going Big versus Going Small: Lithic Miniaturization in Hominin Lithic Technology. Evolutionary Anthropology 28:72-85.

$\mathrm{R}$ Core Team

2020 R: A Language and Environment for Statistical Computing. R Foundation for Statistical Computing, Vienna. https://www.R-project.org/, accessed September 1, 2020.

Restifo, Federico

2013 Tecnología de caza durante el Holoceno Temprano y Medio en la Puna de la Provincia de Salta (República Argentina): Patrones de variación y procesos de cambio. Comechingonia 17:59-84.

Restifo, Federico, Claudio Javier Patané Aráoz, and Javier Piraino

2019 Análisis de puntas de proyectil San Martín de la cuenca de Salinas Grandes (Salta, Argentina) como aporte para la arqueología de cazadores-recolectores Andinos. Latin American Antiquity 30:644-650. 
Rigsby, Catherine A., Paul A. Baker, and Mark S. Aldenderfer

2003 Fluvial History of the Rio Ilave Valley, Peru, and Its Relationship to Climate and Human History. Palaeogeography, Palaeoclimatology, Palaeoecology 194:165-185.

Scott, John, and Emil Fredericson

1951 The Causes of Fighting in Mice and Rats. Physiological Zoology 24:273-309.

Shott, Michael J.

1997 Stones and Shafts Redux: The Metric Discrimination of Chipped-Stone Dart and Arrow Points. American Antiquity 62:86-101.

Sitton, Jase, Brett Story, Briggs Buchanan, and Metin I. Eren 2020 Tip Cross-Sectional Geometry Predicts the Penetration Depth of Stone-Tipped Projectiles. Scientific Reports 10:13289.

Thomas, David Hurst

1978 Arrowheads and Atlatl Darts: How the Stones Got the Shaft. American Antiquity 43:461-472.

Tomka, Steve A.

2013 The Adoption of the Bow and Arrow: A Model Based on Experimental Performance Characteristics. American Antiquity 78:553-569.
Vining, Benjamin R., Byron A. Steinman, Mark B. Abbott, and Arielle Woods

2018 Paleoclimatic and Archaeological Evidence from Lake Suches for Highland Andean Refugia during the Arid Middle-Holocene. Holocene 29:328-344.

Whittaker, John C.

1994 Flintknapping: Making and Understanding Stone Tools. University of Texas Press, Austin.

Whittaker, John C., Devin B. Pettigrew, and Ryan J. Grohsmeyer

2017 Atlatl Dart Velocity: Accurate Measurements and Implications for Paleoindian and Archaic Archaeology. PaleoAmerica 3:161-181.

Winterhalder, Bruce P., and R. B. Thomas

1978 Geoecology of Southern Highland Peru: A Human Adaptation Perspective. Occasional Paper No. 27. Institute of Arctic and Alpine Research, University of Colorado, Boulder.

Submitted August 6, 2020; Revised February 1, 2021; Accepted July 12, 2021 